Check for updates

Cite this: RSC Adv., 2019, 9, 27406

\title{
Preparation and thermal treatment influence on Pt- decorated electrospun carbon nanofiber electrocatalysts $\uparrow$
}

\author{
Igor I. Ponomarev, (D) *a Olga M. Zhigalina, bc Kirill M. Skupov, (D) a \\ Alexander D. Modestov, ${ }^{d}$ Victoria G. Basu, (D) ${ }^{\text {b }}$ Alena E. Sufiyanova, ${ }^{\text {bc }}$ \\ Ivan I. Ponomarev ${ }^{\mathrm{a}}$ and Dmitry Y. Razorenov (D) $^{a}$
}

Crystalline platinum nanoparticles supported on carbon nanofibers were synthesized for use as an electrocatalyst for polymer electrolyte membrane fuel cells. The nanofibers were prepared by a method of electrospinning from polymer solution with subsequent pyrolysis. Pt nanoneedles supported on polyacrylonitrile pyrolyzed electrospun nanofibers were synthesized by chemical reduction of $\mathrm{H}_{2}\left[\mathrm{PtCl}_{6}\right]$ in aqueous solution. The synthesized electrocatalysts were investigated using scanning, high resolution transmission and scanning transmission electron microscopies, EDX analysis and electron diffraction. The shape and the size of the electrocatalyst crystal Pt nanoparticles were controled and found to depend on the method of $\mathrm{H}_{2}\left[\mathrm{PtCl}_{6}\right]$ reduction type and on conditions of subsequent thermal treatment. Soft Pt reduction by formic acid followed by $100{ }^{\circ} \mathrm{C}$ thermal treatment produced needle-shape Pt nanoparticles with a needle length up to $25 \mathrm{~nm}$ and diameter up to $5 \mathrm{~nm}$. Thermal treatment of these nanoparticles at $500{ }^{\circ} \mathrm{C}$ resulted in partial sintering of the Pt needles. When formic acid was added after $24 \mathrm{~h}$ from the beginning of platinization, $\mathrm{Pt}$ reduction resulted in small-size spherical Pt nanoparticle of less than $10 \mathrm{~nm}$ in diameter. Reduction of $\mathrm{H}_{2}\left[\mathrm{PtCl}_{6}\right]$, preadsorbed on electrospun nanofibers in formic acid with further treatment in $\mathrm{H}_{2}$ flow at $500{ }^{\circ} \mathrm{C}$, resulted in intensive sintering of platinum particles, with formation of conglomerates of $50 \mathrm{~nm}$ in size, however, individual particles still retain a size of less than $10 \mathrm{~nm}$. Electrochemically active surface area (ECSA) of Pt/C catalyst was measured by electrochemical hydrogen adsorption/desorption measurements in $0.5 \mathrm{M} \mathrm{H}_{2} \mathrm{SO}_{4}$. ECSA of needle-shape Pt nanoparticles was $25 \mathrm{~m}^{2}$ $\mathrm{g}^{-1}$. It increased up to $31 \mathrm{~m}^{2} \mathrm{~g}^{-1}$ after thermal treatment at $500{ }^{\circ} \mathrm{C}$, likely, due to amorphous structures removal from carbon nanofibers and retaining of Pt nanoneedle morphology. ECSA of small-size spherical Pt nanoparticles was $26 \mathrm{~m}^{2} \mathrm{~g}^{-1}$. Further thermal treatment at $500{ }^{\circ} \mathrm{C}$ in vacuum decreased ECSA down to $20 \mathrm{~m}^{2} \mathrm{~g}^{-1}$ due to Pt sintering and Pt active sites deactivation. The thermal treatment of small-size spherical Pt nanoparticles in $\mathrm{H}_{2}$ flow at $500{ }^{\circ} \mathrm{C}$ produced agglomerates of $\mathrm{Pt}$ nanoparticles with ECSA of $14 \mathrm{~m}^{2} \mathrm{~g}^{-1}$.

rsc.li/rsc-advances

Received 30th July 2019

Accepted 24th August 2019

DOI: $10.1039 /$ c9ra05910e progressive part of the FC industry. ${ }^{1-5}$ Further development of polymer membrane FCs depends on finding new functional materials as they require a durability increase of the membraneelectrode assembly (MEA), containing essential parts such as electrodes and membranes. ${ }^{\mathbf{1 , 6}, 7}$ Despite current PEM FC applications in micro-combined heat and power $(\mu \mathrm{CHP})$ systems $^{8}$ and auxiliary power units $^{9}$ (APU), an increase of durability of the electrodes for PEM FC is an important challenge for further development of given area of hydrogen energy studies. ${ }^{\mathbf{1 0 - 1 4}}$ Most of commercial electrodes are based on carbon black which degrades under acidic fuel cell operation conditions, especially at high temperatures., ${ }^{\mathbf{1 1 0 , 1 4}}$ Many carbon nanostructured materials e.g. carbon nanofibers (CNF) are known as more durable materials compared to carbon black, ${ }^{15-18}$ and their application as metal-electrocatalyst support in the FC electrode may resolve one of the main FC problems related to the durability issues. 
Pyrolyzed electrospun nanofiber materials with deposited Pt electrocatalyst correspond to the aim to increase durability of PEM FC electrodes, however, their electrocatalytic properties may substantially vary with thermal treatment at different conditions. It is known that the heat treatment of Pt electrocatalyst on carbon support may induce a more uniform Pt distribution resulting in well-defined cubo-octahedron crystallites compared with starting irregular Pt. ${ }^{19}$ Also, heat treatment at $400-550{ }^{\circ} \mathrm{C}$ lead to the highest increase in platinum crystallinity, at the same time, improving platinum particle-size distribution. $^{20}$ The understanding of post-platinization thermal treatment effect on Pt electrocatalyst properties would lead to optimization and better performance of electrochemical power sources.

Electrospinning is a method which allows producing polymer nanofibers from polymer solutions, for example, polyacrylonitrile (PAN) solution. ${ }^{21-23}$ Then, microporous CNFs are obtained after carbonization (pyrolysis). ${ }^{24}$ Earlier, we have shown that electrospun CNFs (PAN, or polyheteroarylene based $)^{25-28}$ are suitable for being a support for Pt nanoparticle electrocatalyst in polymer membrane fuel cell tests ${ }^{\mathbf{2 9 - 3 4}}$ with a shown possible use of polybenzimidazole-type $\mathrm{s}^{33,35}$ and other polyheteroarylene ${ }^{36,37}$ membranes for fuel cells. Our approach allows to uniformly introduce $\mathrm{Ni}^{0}$ and $\mathrm{ZrO}_{x}$ into carbon nanofibers using electrospinning method, which is important for electrochemical applications. ${ }^{25,29}$ Similar Ni, Co and Zn introduction into CNF by electrospinning was also reported and confirmed. ${ }^{38,39}$ However, further studies are required as fuel cell performance strongly depend on variations in Pt/CNF preparation and post-preparation treatment which strongly influences its morphology. To understand the Pt/CNF preparation effect on fuel cell performance it is important to observe the influence of the Pt/CNF preparation method on the appearance of Pt nanoparticles and CNF in the electrode. Evidently, different Pt/CNF morphology leads to different platinum electrochemically active surface area (ECSA) which is a fundamental measure of Pt-electrocatalyst performance for many electrochemical power sources.

In the current study we present the influence of Pt deposition parameters and post-deposition thermal treatment influence on $\mathrm{Pt} / \mathrm{CNF}$ morphology and Pt electrochemically active surface area.

\section{Experimental}

\section{Pt-decorated carbon nanofiber electrocatalyst preparation}

Electrospinning. The industrial high-molecular $\left(M_{\mathrm{w}} 150\right.$ $\mathrm{kDa}$ ) polyacrylonitrile (PAN) was used for carbon nanofiber paper fabrication. $100 \mathrm{~g}$ of $7 \%$ wt DMF solution of PAN polymer and $0.57 \mathrm{~g}$ of carbon black Vulcan ${ }^{\circledR} \mathrm{XC72}$ were sonicated in an ultrasonic bath at $50{ }^{\circ} \mathrm{C}$ for $4 \mathrm{~h}$. A solution of $0.35 \mathrm{~g}$ nickel(II) acetate tetrahydrate $\left(\mathrm{Ni}(\mathrm{OAc})_{2} \cdot 4 \mathrm{H}_{2} \mathrm{O}\right)$ in $2 \mathrm{~mL}$ of DMF was mixed with $0.018 \mathrm{~g}$ zirconium(Iv) chloride $\left(\mathrm{ZrCl}_{4}\right)$ in $1 \mathrm{~mL}$ of DMF, then, sonicated in ultrasonic bath at $50{ }^{\circ} \mathrm{C}$ to introduce $\mathrm{Zr}$ and $\mathrm{Ni}$ into final carbonized material (potentially, as a rule, $\mathrm{Ni}^{\circ}$ helps graphitization during pyrolysis step, ${ }^{25}$ and $\mathrm{ZrO}_{x}$ is prone to improve proton conductivity due to zirconium hydrophosphate formation during fuel cell operation time ${ }^{29}$ ). A process of the electrospinning was conducted using Elmarco Nanospider ${ }^{\mathrm{TM}}$ NS LAB (Czech Republic). The electrospinning was carried out at $26{ }^{\circ} \mathrm{C}$, at relative humidity of $28 \%$, distance between the electrodes of $190 \mathrm{~mm}$, linear carrier velocity of $3 \mathrm{~mm} \mathrm{~s}^{-1}$ and carriage velocity of $300 \mathrm{~mm} \mathrm{~s}^{-1}$, at $75 \mathrm{kV}$ and 0.06 mA.

Stabilization and carbonization. Nanofiber mat with a thickness of $10-100 \mu \mathrm{m}$ and nanofiber diameter of $150-$ $300 \mathrm{~nm}$ was treated by oxidative (stabilizing) heating at $350{ }^{\circ} \mathrm{C}$ in air. Stabilized materials were carbonized on a pyrolysis step under vacuum $\left(10^{-5}\right.$ Torr $)$ at $1000{ }^{\circ} \mathrm{C}$ for $2 \mathrm{~h}$ at $3{ }^{\circ} \mathrm{C} \mathrm{min}^{-1}$ heating rate resulting carbon nanofiber paper. Electrospun polyacrylonitrile (PAN) nanofibers were annealed to achieve partial graphitization and to increase their electrical conductivity and strength properties. The resulting CNF is in a form of entire mat and may be used as an FC gas-diffusion electrode (GDE) after electrocatalyst nanoparticle deposition. Elemental composition of the resulted material as determined by elemental analysis (based on atomic absorption spectroscopy) was C $85.29 \%$, N 1.85\%, Ni 5.95\%, Zr 1.2\%.

Platinum deposition and post-treatment. Platinum nanoparticle deposition on the CNF based materials was conducted in hexachloroplatinic acid $\left(\mathrm{H}_{2}\left[\mathrm{PtCl}_{6}\right]\right)$ aqueous solutions. For samples 1-4, square $(2.6 \times 2.6 \mathrm{~cm}) \mathrm{CNF}$ sample was introduced into $20 \mathrm{~mL}$ aqueous solution with $21.5 \mathrm{mg}(15.6 \mu \mathrm{mol})$ of added $\mathrm{H}_{2}\left[\mathrm{PtCl}_{6}\right] \cdot 6 \mathrm{H}_{2} \mathrm{O}$ and $0.5 \mathrm{~g}(10.9 \mathrm{mmol})$ of formic acid ( $\left.\mathrm{HCOOH}\right)$ used as a reducing agent, and left overnight at room temperature. The resulting sample (after drying at $100{ }^{\circ} \mathrm{C}$ under vacuum) was divided into 4 equal parts and treated at different thermal conditions. For samples 1-3, platinized CNF based materials were treated at 100,300 and $500{ }^{\circ} \mathrm{C}$ under vacuum subsequently. Sample 4 was treated at $500{ }^{\circ} \mathrm{C}$ under flow of dry hydrogen. For samples 5-8, (after drying at $100{ }^{\circ} \mathrm{C}$ under vacuum) square $(2.6 \times 2.6 \mathrm{~cm})$ CNF sample was introduced into $20 \mathrm{~mL}$ aqueous solution with $21.5 \mathrm{mg}(15.6 \mu \mathrm{mol})$ of added $\mathrm{H}_{2}\left[\mathrm{PtCl}_{6}\right] \cdot 6 \mathrm{H}_{2} \mathrm{O}$. After $24 \mathrm{~h}, 0.5 \mathrm{~g}(10.9 \mathrm{mmol})$ of formic acid $(\mathrm{HCOOH})$ was added as a reducing agent and left overnight at room temperature. The resulting sample Pt/CNF was divided into 4 equal parts and treated at different thermal conditions. For samples 5-7, Pt/CNF based materials were treated at 100, 300 and $500{ }^{\circ} \mathrm{C}$ under vacuum subsequently. Sample 8 was treated at $500{ }^{\circ} \mathrm{C}$ under flow of dry hydrogen. Samples $\mathbf{1}$ and $\mathbf{5}$ (treated at $100{ }^{\circ} \mathrm{C}$ ) were considered as reference samples. Elemental composition of platinized material for samples 1-4 was Pt 28.2\%, C 61.2\%, N 1.3\%, Ni 4.3\%, Zr 0.9\%. For samples 5-8, Pt 27.8\%, C 61.6\%, N 1.4\%, Ni 4.3\%, Zr 0.9\%.

\section{Electron microscopy studies}

Structural analysis was performed by transmission electron microscopy (TEM), high-resolution transmission electron microscopy (HRTEM), scanning transmission electron microscopy (STEM), electron diffraction, and energy-dispersive analysis (EDA), using FEI Tecnai Osiris microscope equipped with high-angle annular dark field detector (HAADF) at accelerating voltage of $200 \mathrm{kV}$, respectively. Elemental analysis and mapping 
were carried out using a special Super XEDS system (including four silicon Bruker detectors), whose design provides rapid (several minutes) acquisition of large-area elemental maps. For electron microscopy structural investigations, the samples of carbon nanofiber paper were dispersed in acetone using ultrasonic bath for 5-30 min to get single fibers. The suspension obtained was dropped onto $\mathrm{Cu}$ lacey carbon grids.

\section{XRD studies}

$\mathrm{X}$-Ray analysis of the samples was carried out using Co $\mathrm{K} \alpha$ radiation. The qualitative phase analysis was performed in the range of diffraction angles $2 \theta 30-130^{\circ}$ with a step of $\Delta 2 \theta 0.07^{\circ}$ and exposure at the point $\tau 1.5 \mathrm{~s}$. The following slit system was used during the experiment: a motorized $1 \mathrm{~mm}$ slit for the X-ray source, Soller gap with a distance of $2.5 \mathrm{~mm}$ between the plates for the X-ray source and detector. To determine the Pt and Ni crystal lattice parameters, Pt (311), Pt (222), Ni (220) and Ni (311) reflections were chosen ( $2 \theta$ step $0.02^{\circ}$, exposure $2 \mathrm{~s}$ ); the gap in the X-ray source was reduced to $0.25 \mathrm{~mm}$. Each reflection was shot 3 times with the sample reinstalled. Since the diffraction peaks have a large width, the error in determining the crystal lattice parameters is $\sim 0.001 \AA$.

\section{Cyclic voltammetry}

Evaluation of the electrochemically active surface area (ECSA) of platinum in the synthesized electrocatalysts was performed at room temperature in a three-electrode cell with separated compartments by electrochemical hydrogen adsorption/ desorption measurements. ${ }^{\mathbf{4 0 , 4 1}}$ Measurements of the electrochemical hydrogen underpotential deposition is a popular approach to assess the ECSA for pure and alloyed Pt catalysts. Hydrogen atoms at Pt surface are produced by electrochemical reduction of protons from aqueous electrolyte. The number of surface atoms at polycrystalline Pt is evaluated from the charge associated with oxidation of adsorbed hydrogen in the potential range 0 to $\sim 0.4 \mathrm{~V}$ versus reversible hydrogen electrode, using the stoichiometry of one adsorbed $\mathrm{H}$ atom per single surface $\mathrm{Pt}$ atom. The electrochemical cell was filled with $0.5 \mathrm{M} \mathrm{H}_{2} \mathrm{SO}_{4}$. Pt wire and $\mathrm{Ag} / \mathrm{AgCl}$-saturated $\mathrm{KCl}(0.2 \mathrm{~V}$ vs. standard hydrogen electrode (SHE)) were used as a counter and reference electrodes, respectively. The potential readings are given versus SHE. The working electrode was a polished graphite disk with a diameter of $1.6 \mathrm{~cm}^{2}$ in a polytetrafluoroethylene (PTFE) holder. The disk electrode surface was coated by the studied catalyst by the repeated placing parts of the electrocatalyst ink with intermediate drying at $60{ }^{\circ} \mathrm{C}$. Catalyst inks were prepared by dispersing $2-3 \mathrm{mg}$ of a catalyst $\mathrm{Pt}$ / CNF ultrasonically in $0.4 \mathrm{~mL}$ of aqueous solution containing $0.2 \mathrm{~mL}$ of isopropanol and $0.01 \mathrm{~mL}$ of $5 \mathrm{wt} \%$ Nafion solution. 100 $\mu \mathrm{L}$ of the ink was dispersed onto the surface of the disk electrode. The voltammograms were recorded at $50 \mathrm{mV} \mathrm{s}^{-1}$ potential scan rate. The potential was cycled until a stable voltammogram was obtained. Usually it took less than 50 cycles for the voltammogram stabilization. The ECSA was evaluated by integration of the hydrogen adsorption/desorption areas of the cyclic voltammograms (CV), assuming $0.21 \mathrm{mC} \mathrm{cm}_{\mathrm{Pt}}{ }^{-2}$. The capacitance of the double layer that was formed at the electrode/electrolyte interface was taken into account. On the voltammograms, the current readings are normalized per unit of Pt loading at the graphite disk electrode.

\section{Results and discussion}

Different thermal treatment of Pt/CNF materials is expected to change platinum morphology. As a result, treated materials may differ in their functional properties, which opens the door to obtain materials with predictable properties. For example, different Pt morphology affects FC performance when used as electrocatalyst. Cyclic voltammetry (CV) provides a way to find platinum ECSA. The rate of the oxygen reduction at different modified Pt catalysts is usually related per Pt ECSA in the particular catalyst. Pt morphology, revealed by electron microscopy might be related with ECSA obtained by CV and parameters of Pt/CNF treatment. The data for ECSA for different samples and cyclic voltammograms for samples 1, 3, 5 and 7 are presented on Table 1 and Fig. 1. The shape of the voltammograms in the potential region of hydrogen adsorption/ desorption slightly deviates from that of pure polycrystalline $\mathrm{Pt}^{\mathbf{4 0 , 4 1}}$ apparently due to possible formation of alloys with $\mathrm{Ni}$ on the Pt-Ni surface contact.

\section{Nanoneedle platinum}

Sample 1 which was obtained by platinization with immediate formic acid addition and further treatment at $100{ }^{\circ} \mathrm{C}$, shows ECSA of $24.5 \mathrm{~m}^{2} \mathrm{~g}^{-1}$. Fig. 2 shows TEM images and the corresponding electron diffraction patterns characterizing the fiber structure and the morphology of the Pt coating (particles). One can see a change in the morphology of some fiber fragments caused by the introduction of Vulcan ${ }^{\circledR}$ carbon black in order to increase a surface area of the fibers (Fig. 2a and S1a see ESI $\dagger$ ). Platinum particles demonstrate a needle shape (Fig. 2b), the diameter and length of needles are up to 5 and $25 \mathrm{~nm}$, respectively. Particles are located mainly in the surface layer of fibers, and some of them are oriented at an angle to the fibers' axis. Some particles have a spherical shape and a size of several $\mathrm{nm}$, or represent splices (Fig. 2c).

The TEM images clearly show a porous structure of the fibers formed by the loops of graphene planes that arise during the annealing process, as described in ref. 25. Some particles form necklaces. A ring diffraction pattern (Fig. 2d) indicates the presence of small Pt particles and the formation of crystalline layers in the nanofiber's body.

When the sample was treated at $300{ }^{\circ} \mathrm{C}$ the ECSA decreased to $18 \mathrm{~m}^{2} \mathrm{~g}^{-1}$, probably, due to some degradation of Pt nanoparticles. At the same time, morphology does not change significantly. The morphology of platinum varies slightly: fewer areas with needle-like Pt particles, with a small part of particles having a size of about $1 \mathrm{~nm}$. The diffraction pattern (Fig. 2e) indicates a local preferred orientation of the crystal layers in the body of the fibers, as well as a slight increase in size of platinum crystals. Individual bright reflexes correspond to nickel particles present in the sample. ${ }^{29}$ 
Table 1 ECSA values for samples 1-8

\begin{tabular}{|c|c|c|}
\hline Sample, immediate $\mathrm{HCOOH}$ addition & Thermal treatment conditions & ECSA, $\mathrm{m}^{2} \mathrm{~g}^{-1}$ \\
\hline 1 & $100^{\circ} \mathrm{C}$, vacuum & 24.5 \\
\hline 2 & $300^{\circ} \mathrm{C}$, vacuum & 18.0 \\
\hline 3 & $500{ }^{\circ} \mathrm{C}$, vacuum & 30.7 \\
\hline 4 & $500^{\circ} \mathrm{C}, \mathrm{H}_{2}$ flow & 4.7 \\
\hline Sample, $\mathrm{HCOOH}$ addition after $24 \mathrm{~h}$ & Thermal treatment conditions & ECSA, $m^{2} g^{-1}$ \\
\hline 5 & $100^{\circ} \mathrm{C}$, vacuum & 25.6 \\
\hline 6 & $300^{\circ} \mathrm{C}$, vacuum & 28.9 \\
\hline 7 & $500^{\circ} \mathrm{C}$, vacuum & 19.8 \\
\hline 8 & $500{ }^{\circ} \mathrm{C}, \mathrm{H}_{2}$ flow & 14.2 \\
\hline
\end{tabular}

Further treatment at $500{ }^{\circ} \mathrm{C}$ leads to partial sintering, but the ECSA surprisingly increased up to $31 \mathrm{~m}^{2} \mathrm{~g}^{-1}$. It might be related with Pt activation by thermal treatment, at the same time, visibly, the morphology is changed but Pt-needles are still preserved. Also, heat treatment at $400-550{ }^{\circ} \mathrm{C}$ lead to the highest increase in platinum crystallinity, at the same time, improving platinum particle-size distribution, which may explain higher ECSA. An increase of thermal treatment temperature up to $500{ }^{\circ} \mathrm{C}$ also leads to a significant change in the structure of platinum coating. Fig. 3 shows the images of three fibers with different morphology of platinum particles. In the first case (Fig. 3a), one can see a preservation of the needle structure of platinum and, at the same time, a sintering of particles on the fiber surface. In the second case (Fig. 3b), only a dense "crust" of the particles sintered during the annealing is present (the arrows indicate clear contours, indicating the formation of a continuous "crust" on the fiber surface). In Fig. 3c, there is a fragment of a fiber with non-sintered Pt particles. In general, the particles are of equilibrium shape, different sizes and do not form a continuous cover on the fiber surface. Apparently, a solid "crust" forms in places where the coating is thick, and separate particles remain in places depleted in platinum. In the diffraction pattern (Fig. 3d), one can observe the fragmentation effect for rings corresponding to platinum, which is caused by partial platinum nanoparticle recrystallization and increase in size.

Comparison of TEM images for samples $\mathbf{1}$ and $\mathbf{3}$ is shown on Fig. 4. For sample $\mathbf{1}$ (heat-treatment at $100{ }^{\circ} \mathrm{C}$ ), amorphous
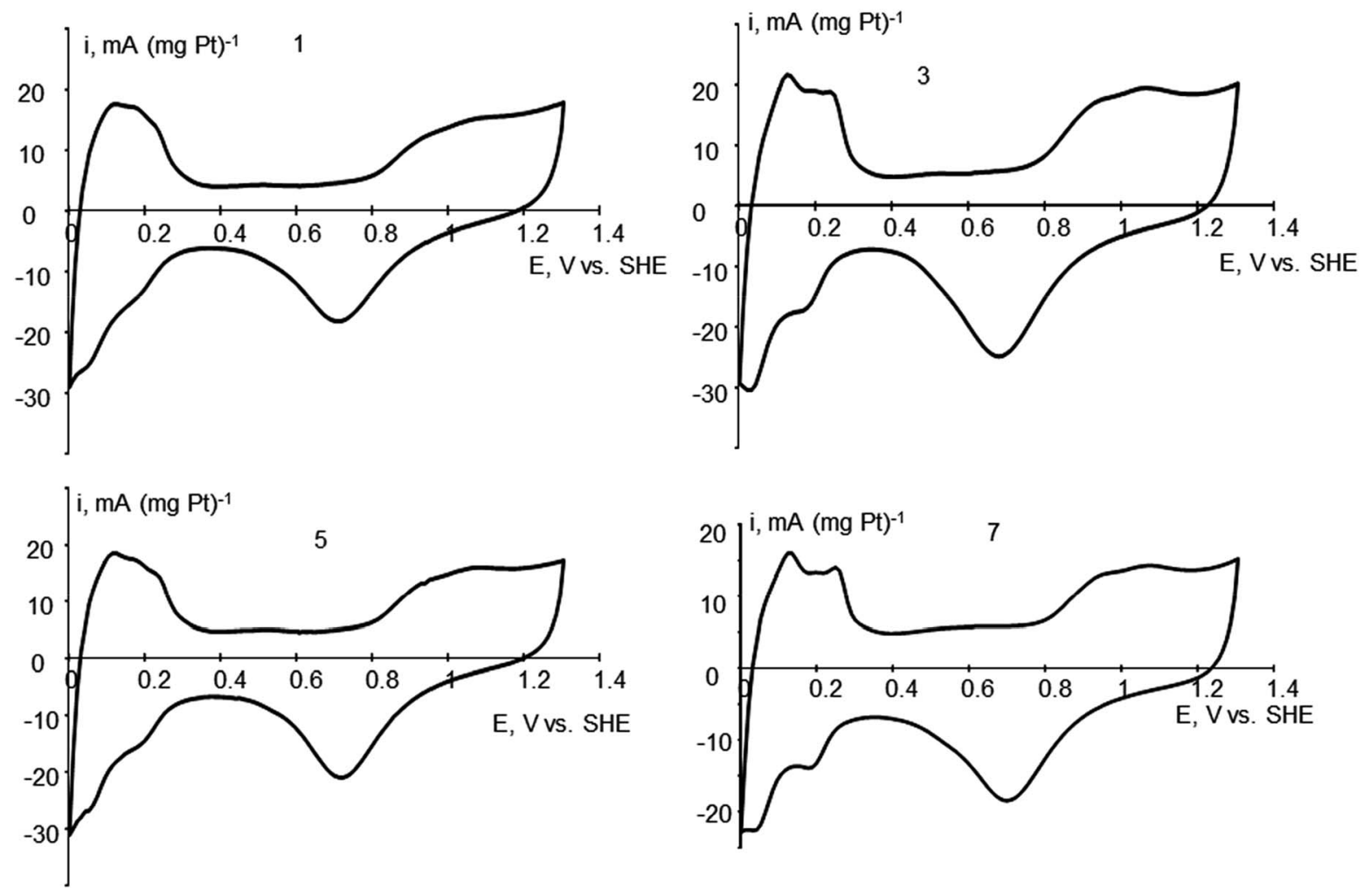

Fig. 1 Cyclic voltammograms for samples 1, 2, 5 and 7. 
structures are observed on the surface of carbon nanofibers (a and b). For sample 3 (heat-treatment at $500{ }^{\circ} \mathrm{C}$ ), carbon nanofiber surface and electrocatalyst metal nanoparticle surface are free of the amorphous structures (c and d). So that, after treatment at $500{ }^{\circ} \mathrm{C}$, the amorphous structures completely disappear. It leads to cleaner surface, better accessibility of the electrocatalyst and higher ECSA value. At the same time, the needle microstructure of platinum is preserved, and deactivation of the electrocatalyst active sites due to partial sintering does not happen. These effects affect ECSA and explain its increase for sample 3.

Thermal treatment of the sample at $500{ }^{\circ} \mathrm{C}$ in a flow of dry $\mathrm{H}_{2}$ leads to sintering and decrease of ECSA to $4.7 \mathrm{~m}^{2} \mathrm{~g}^{-1}$ with total
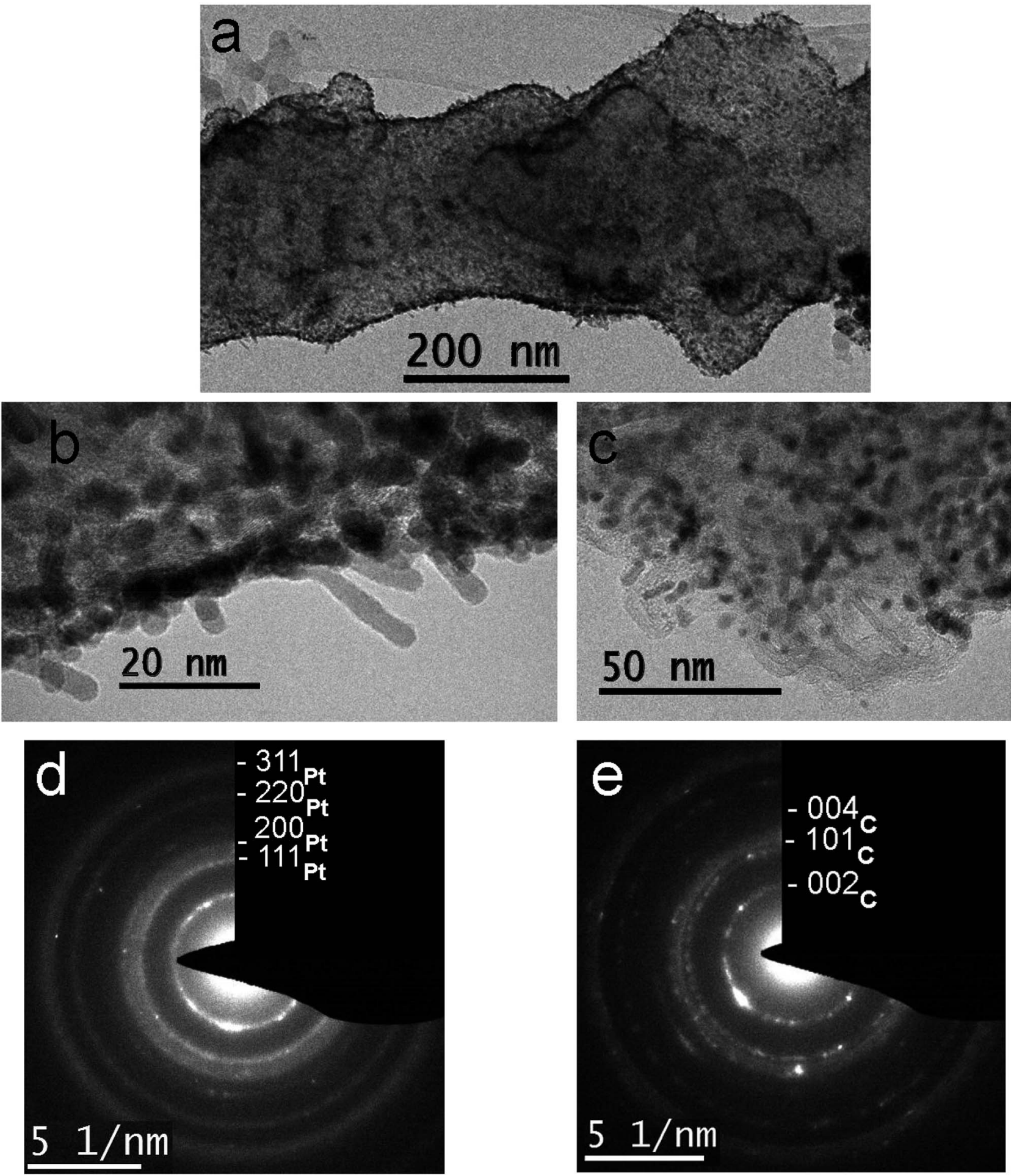

Fig. 2 Structure of 1: (a) a change in morphology of some areas caused by introduction of Vulcan ${ }^{\text {XC }}$-72 carbon black; (b) TEM image of a fiber surface covered with Pt needles; (c) porous structure of the fibers formed by the loops of graphene planes; (d) SAED pattern for 1. (e) SAED pattern for 2 . 

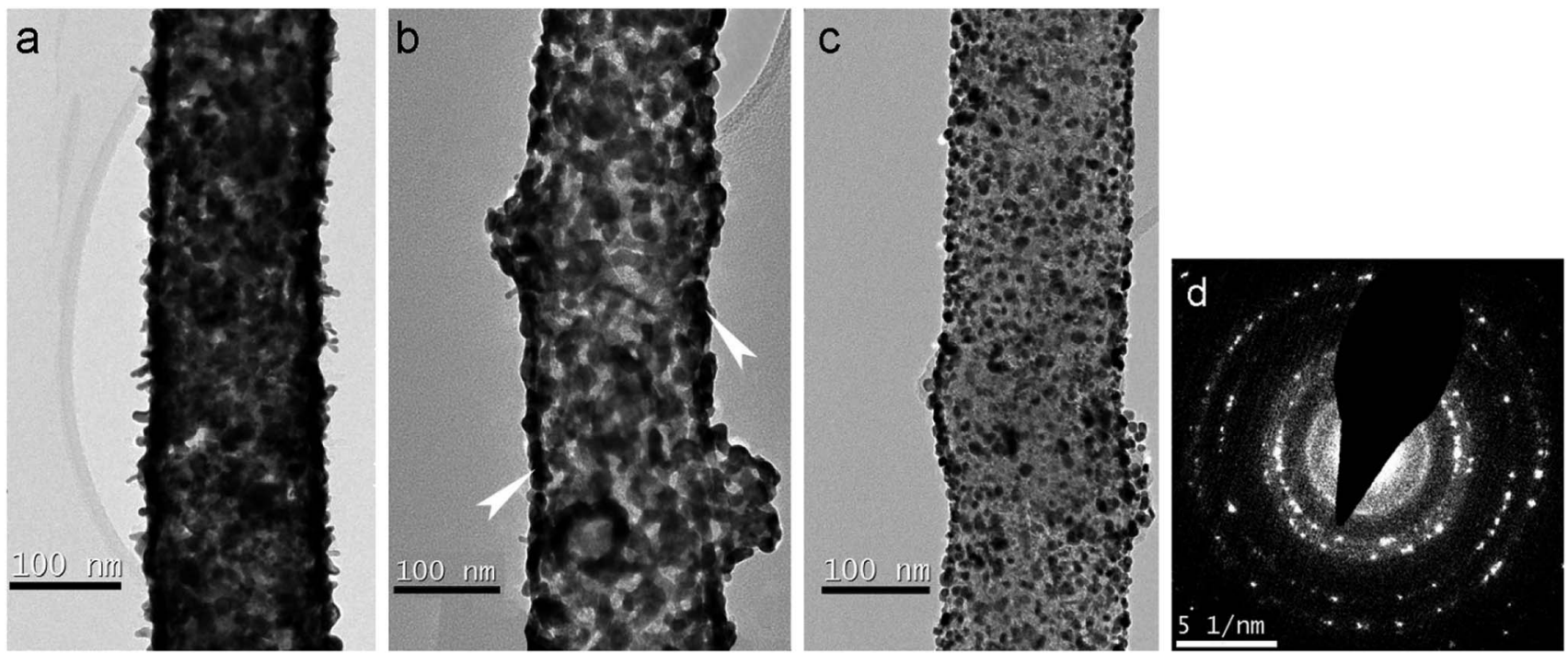

Fig. 3 TEM images of fibers with different morphology of platinum nanoparticles (sample 3): (a) a needle structure of Pt and sintering of Pt particles; (b) a"crust" of the particles sintered during annealing (the arrows indicate clear contours, indicating the formation of a continuous "crust" on the fiber surface); (c) fragment of a fiber with non-sintered Pt particles; (d) corresponding SAED pattern for (b).

loss of Pt-needles. Treatment at $500{ }^{\circ} \mathrm{C}$ in a stream of dry hydrogen was carried out to study the effect of a harder treatment (compared to soft reduction by formic acid only). At the same time, the structural processes noted for the previous sample develop noticeably. In Fig. 5-7 and S2 (see ESI†) one can see a fragment of a fiber with a typical structure where the
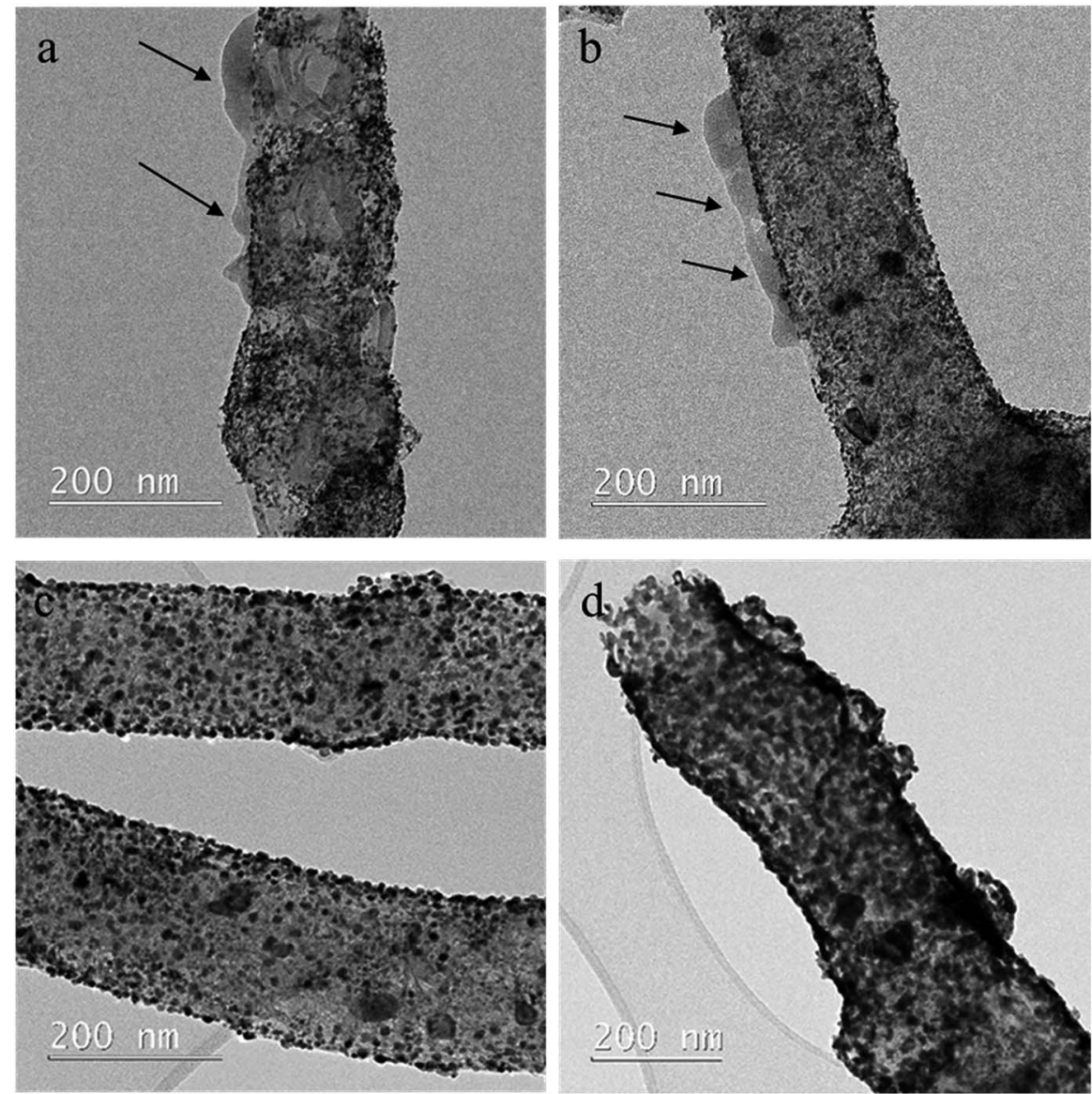

Fig. 4 Amorphous structures on the surface of carbon nanofibers for sample 1 (a and b). Carbon nanofiber surface and electrocatalyst metal nanoparticle surface, free of the amorphous structures for sample 3 (c and d). 

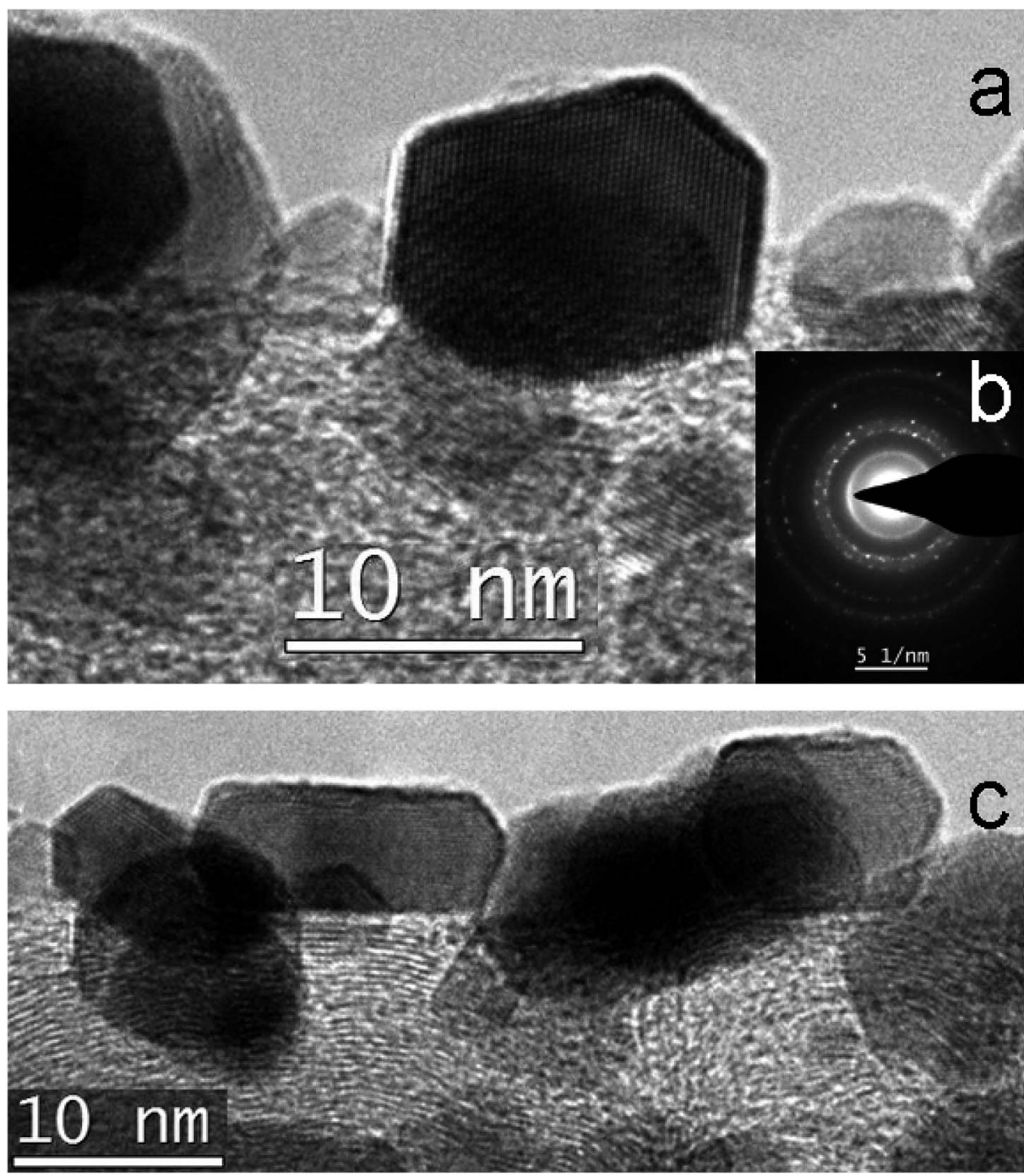

Fig. 5 Structure of 4: (a) Detailed HREM image of Pt crystals; (b) SAED pattern; (c) HREM image of Pt faceted crystals.

process of sintering and enlargement of platinum particles is more intensive. At the same time, faceted crystals up to 20$30 \mathrm{~nm}$ in size are formed on the surface of the fibers. Some of them demonstrate an equiaxial shape (Fig. $5 \mathrm{a}$ and b), others are oriented with the long side along the axis of the nanofiber (Fig. 5c). Comparison and analysis in the HAADF STEM image and EDX mapping allow us to conclude the correlation in the locations of Pt, $\mathrm{O}$ and $\mathrm{Zr}$ (Fig. 5 and 6). It may indicate on formation of $\mathrm{ZrO}_{x}$. Earlier we have demonstrated by XPS the absence of platinum oxide on similar materials. ${ }^{29}$ At the elemental maps at higher magnification (Fig. 7), with arrows, which indicate places where a correlation in the location of platinum and oxygen is visible. One can see, that small particles of zirconium oxide are visible. Overlay maps, especially $\mathrm{Zr}-\mathrm{Pt}-\mathrm{O}$, in addition to individual ones demonstrate the correlation too.

\section{Spherical nanoparticle platinum}

Very different data was obtained when formic acid ( $\mathrm{HCOOH})$ addition was delayed by $24 \mathrm{~h}$ after the beginning of platinization. Sample $5\left(100{ }^{\circ} \mathrm{C}\right.$ treatment) is similar to $\mathbf{1}$ by ECSA (25.6 $\mathrm{m}^{2} \mathrm{~g}^{-1}$ ), at the same time, Pt morphology is completely different (Fig. 8). No Pt-needles are observed. But small size spherical Pt nanoparticles of less than $10 \mathrm{~nm}$ could be seen only. It may be explained by the fact that no Pt reduction was observed during first $24 \mathrm{~h}$, but $\mathrm{H}_{2}\left[\mathrm{PtCl}_{6}\right]$ solution penetrated into the pores and adsorbed on the surface much better. When a reducing agent was added, the adsorbed $\left[\mathrm{PtCl}_{6}\right]^{2-}$ nucleated into spherical particles.

Further treatment at $300{ }^{\circ} \mathrm{C}$ (sample 6) does not change significantly neither morphology, nor ECSA $\left(28.9 \mathrm{~m}^{2} \mathrm{~g}^{-1}\right)$, however, slight sintering and increasing in particle size are observed on Fig. 9.

Thermal treatment at $500{ }^{\circ} \mathrm{C}$ (sample 7) leads to drastic changes in Pt morphology with sintering of Pt-nanoparticles (Fig. S3a and b, see ESI $\dagger$ ) and lowering of the ECSA value (20 $\left.\mathrm{m}^{2} \mathrm{~g}^{-1}\right)$.

Opposite to sample 3, in the case of sample $7,500{ }^{\circ} \mathrm{C}$ treatment does not lead to ECSA increase, but instead, the ECSA 

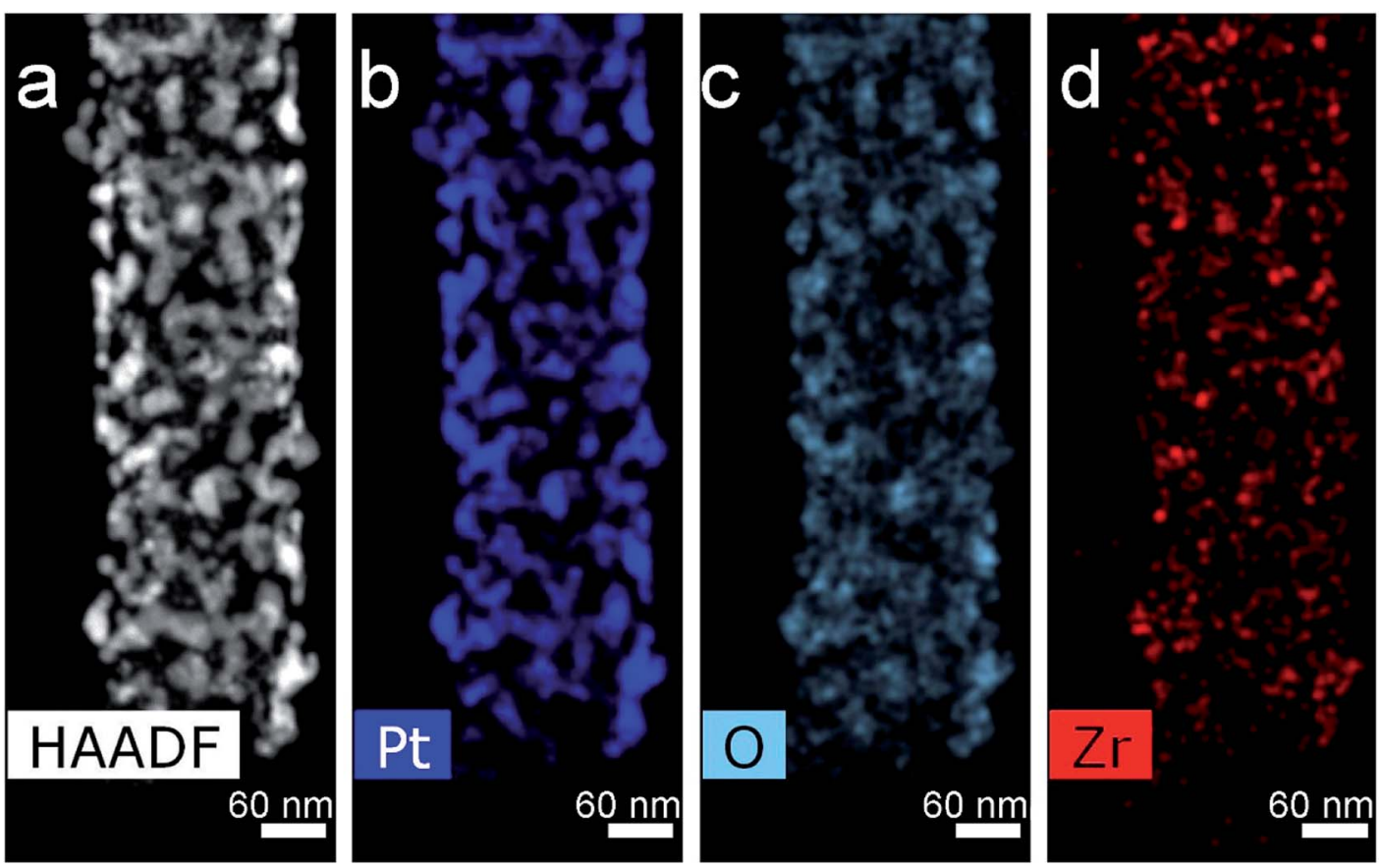

Fig. 6 HAADF STEM image for 4 (a) and EDX mapping for Pt (b), O (c) and $\mathrm{Zr}$ (d).

value is decreased. It can be explained by higher stability of Pt nanoneedles, and much lower stability of small spherical Ptnanoparticles toward thermal treatment. The rings in the diffraction pattern (Fig. S3c, see ESI $\dagger$ ) turn into groups of reflexes, which indicates an increase in size of platinum nanocrystals and deactivation of the electrocatalyst active sites. So that, despite the cleaning effect which happens at $500{ }^{\circ} \mathrm{C}$ leading to disappearance of the amorphous structures and better accessibility of the electrocatalyst, platinum small size spherical microstructure is not preserved and sufficient sintering and particle size increase are observed. It is related to lower stability of $10 \mathrm{~nm}$ platinum sphere crystal structure to $500{ }^{\circ} \mathrm{C}$ treatment, and explains Pt ECSA value decrease compared to the case of nanoneedle platinum microstructure. So that, for smallsize spherical microstructure of Pt, the sintering effect overcomes the cleaning effect, and Pt ECSA decreases.

Thermal treatment at $500{ }^{\circ} \mathrm{C}$ (sample 8) in a flow of dry hydrogen leads to further decrease of ESCA value to $14.2 \mathrm{~m}^{2} \mathrm{~g}^{-1}$

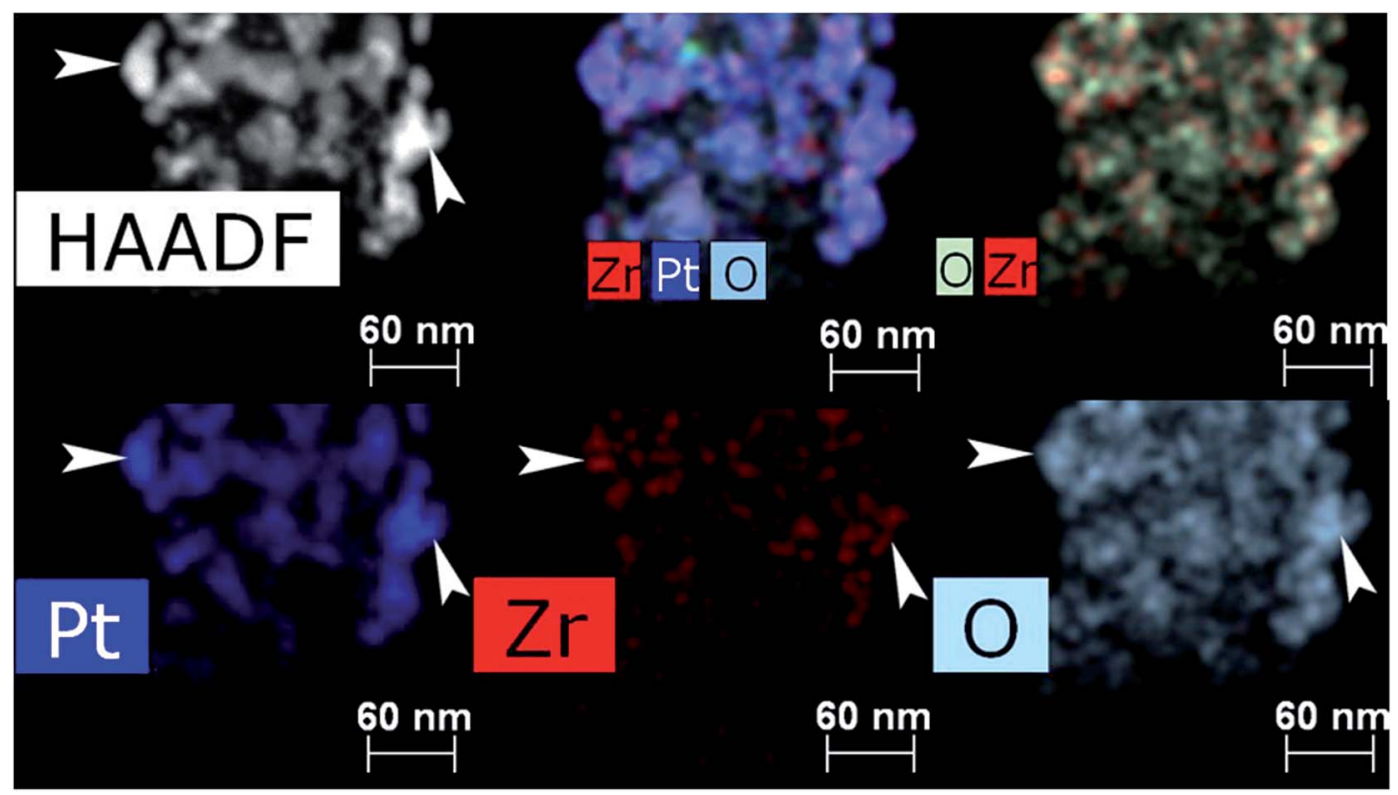

Fig. 7 HAADF STEM image at higher scale for 4. 


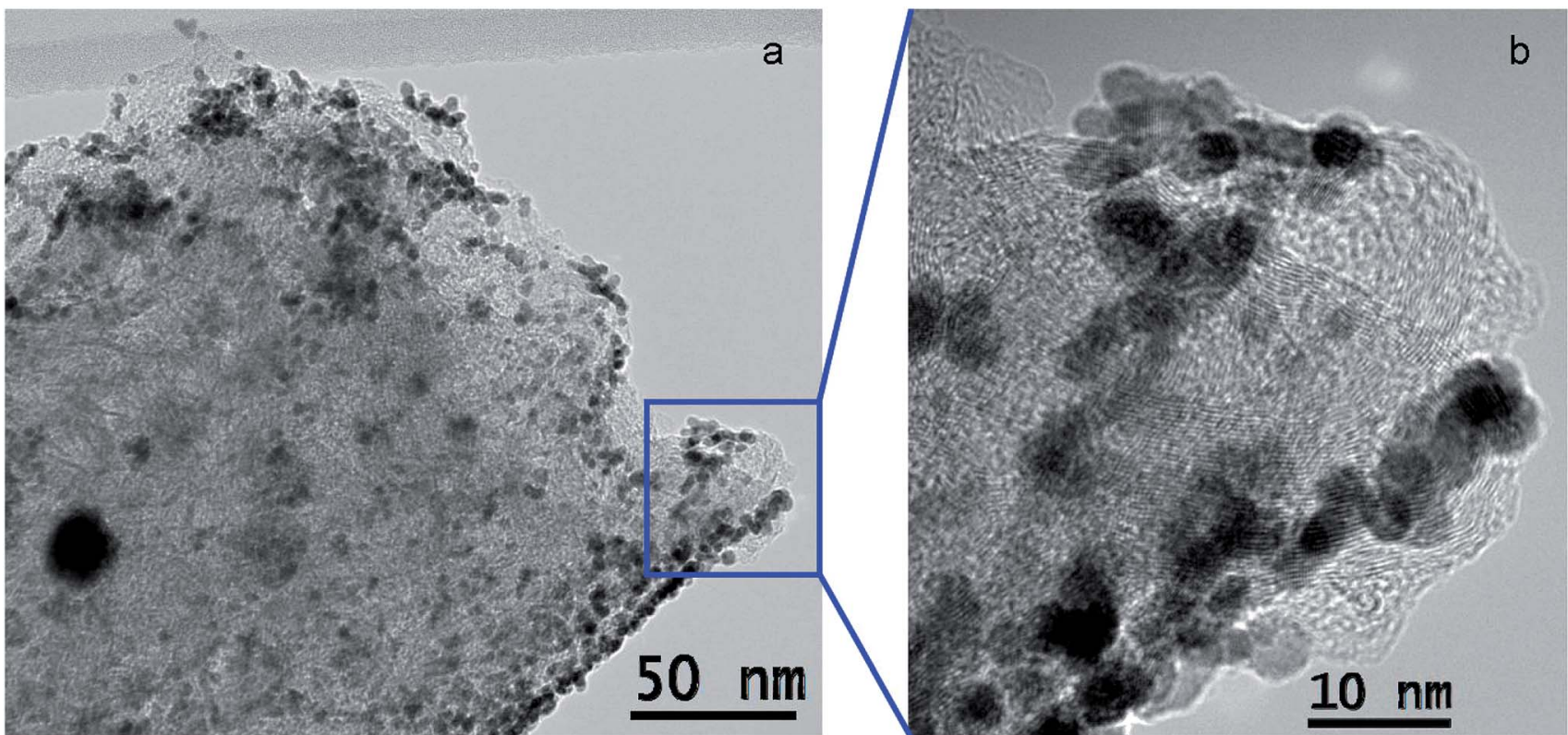

Fig. 8 Structure of 5: (a) TEM image of the top of the fiber; (b) enlarged image of a selected part of (a).

and further degradation of Pt nanoparticles (Fig. 10). Fig. 10a shows a fragment of a fiber with sintered particles well fixed on its surface, individual particles still retain sizes less than $10 \mathrm{~nm}$ (Fig. 10b). In addition to individual large particles, one can observe conglomerates with a size of up to $50 \mathrm{~nm}$, which form a continuous cover on the surface of the filaments (Fig. S4a, see ESI $\dagger$ ) Fig. S4b† demonstrates large faceted particles in size up to $20 \mathrm{~nm}$.
During pyrolysis step, initial polymer nanofibers crystallize forming CNF with sets of parallel straight graphene layers, as it was shown in our previous studies. ${ }^{25}$ In the given study, the nanofibers are pyrolyzed at $1000{ }^{\circ} \mathrm{C}$ and are already partially crystallized. These CNF contain pores which are made by sets of parallel straight graphene layers. These pores are different in size, Fig. S5 (see ESI $\dagger$ ) shows nanofiber parts with large and small pores after heat-treatment at $100{ }^{\circ} \mathrm{C}$ in the absence of platinum.

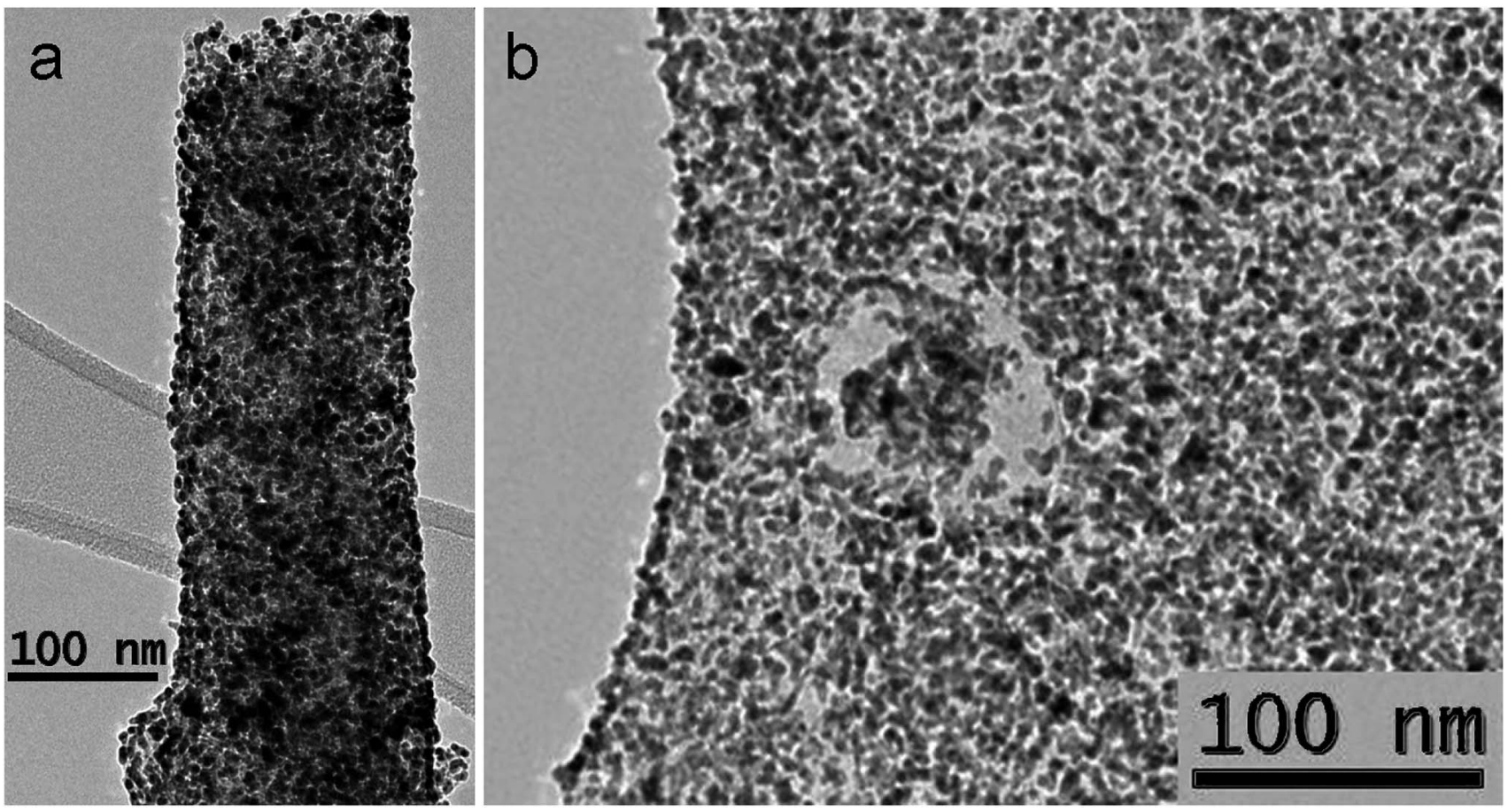

Fig. 9 Structure of 6: (a) TEM image of the fiber; (b) enlarged image of slightly sintered Pt nanoparticles. 

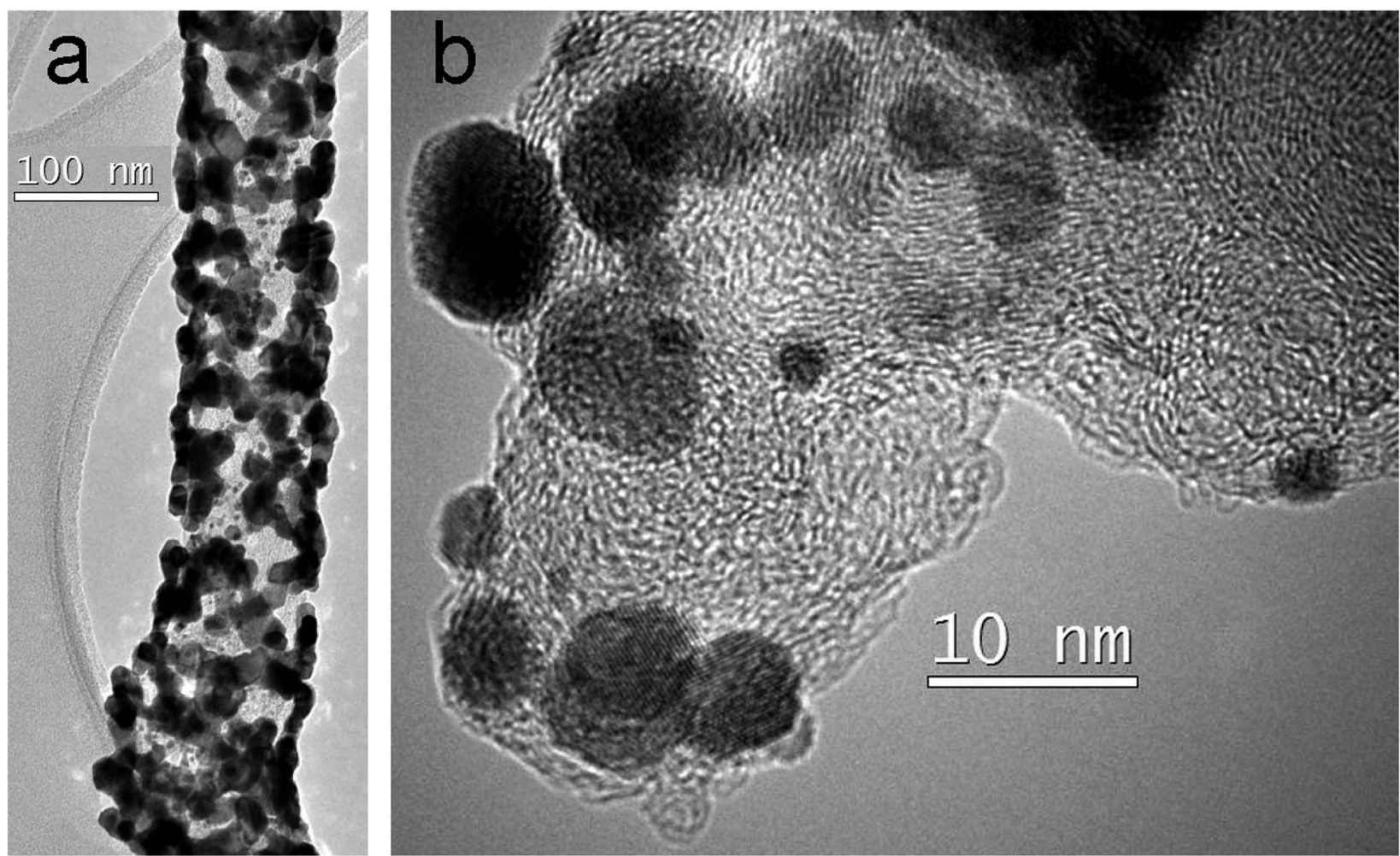

Fig. 10 Structure of 8: (a) TEM image of a fiber; (b) smaller nanoparticles.

Heat-treatment of platinized $\mathrm{CNF}$ at $500{ }^{\circ} \mathrm{C}$ is able to introduce sufficient changes in nanofiber microstructure. For example, after $100{ }^{\circ} \mathrm{C}$ treatment (sample 5), pores which are made by sets of parallel straight graphene layers, located on the edge of platinized carbon nanofiber are clearly seen (Fig. S6†). After $500{ }^{\circ} \mathrm{C}$ treatment (sample 8), the number of pores decreases and the number of layers in graphene sets increases (Fig. S7†). At the same time, the increased in size particles fill the pores, which decrease accessibility of the electrocatalyst and decreases Pt ECSA value. The particles heavily conglomerate, so that, electrocatalyst surface is decreasing (sample 8) after hydrogen treatment at $500{ }^{\circ} \mathrm{C}$.

Earlier detailed studies ${ }^{25}$ of platinum nanoparticles show microfacet formation with a height comparable with a distance between atoms. These steps (microfacets) and higher surface area correspondingly due to small particle size correlate with higher ECSA value. Sintering of nanoparticles leads to microfacet disappearance which decreases Pt ECSA.

\section{XRD analysis}

Taking into account a fact that the samples with platinum coating were exposed to high-temperature thermal treatment, platinum crystal lattice parameter was measured to determine a possibility of platinum interaction with nickel. Fig. 11a and b show the diffraction patterns of samples $\mathbf{1}$ and $\mathbf{3}$ after heating at different temperatures.
In both diffraction patterns for samples $\mathbf{1}$ and $\mathbf{3}$, in addition to $\mathrm{C}$ (002) reflection, the diffraction peak maxima from facecentered cubic Pt and Ni crystal lattices were recorded. It is noteworthy that after thermal treatment at higher temperature of $500{ }^{\circ} \mathrm{C}$ (3), the broadening of the diffraction peaks of $\mathrm{Pt}$ decreases noticeably, and the amount of $\mathrm{Ni}$, which is estimated from the relative intensity of its diffraction peaks, decreases. Fig. S10 (see ESI $\dagger$ ) show the diffraction patterns of samples 6, 7 and 8 after thermally treated at different temperatures and in different media. For diffraction patterns for samples 6, 7 and 8 the same peaks are recorded. Peak broadening is also decreasing by increasing the heating temperature. The decrease does not depend on the medium. Table 2 shows Pt and Ni crystal lattice parameters obtained from XRD calculations.

It can be seen from Table 2 that by increasing the heating temperature, Pt crystal lattice parameter decreases, but the $\mathrm{Ni}$ crystal lattice parameter increases. Both Pt and Ni crystal lattice parameters decrease when heated at $500{ }^{\circ} \mathrm{C}$ under hydrogen flow (7) compared to the values when heated at $500{ }^{\circ} \mathrm{C}$ under vacuum (8). Pt and $\mathrm{Ni}$ lattice parameters are higher for 3 than for 7 when heated to $500{ }^{\circ} \mathrm{C}$ under vacuum.

Considering the dependence of Pt-Ni solid solution lattice parameter from $\mathrm{Ni}$ content to be very close to linear, ${ }^{\mathbf{4 2 , 4 3}}$ and also taking into account lattice parameter values for pure platinum $^{\mathbf{4 4 , 4 5}}$ and nickel ${ }^{45,46}$ metals, the maximal amount of $\mathrm{Ni}$ in $\mathrm{Pt}$ lattice during the thermal treatment can be estimated. 

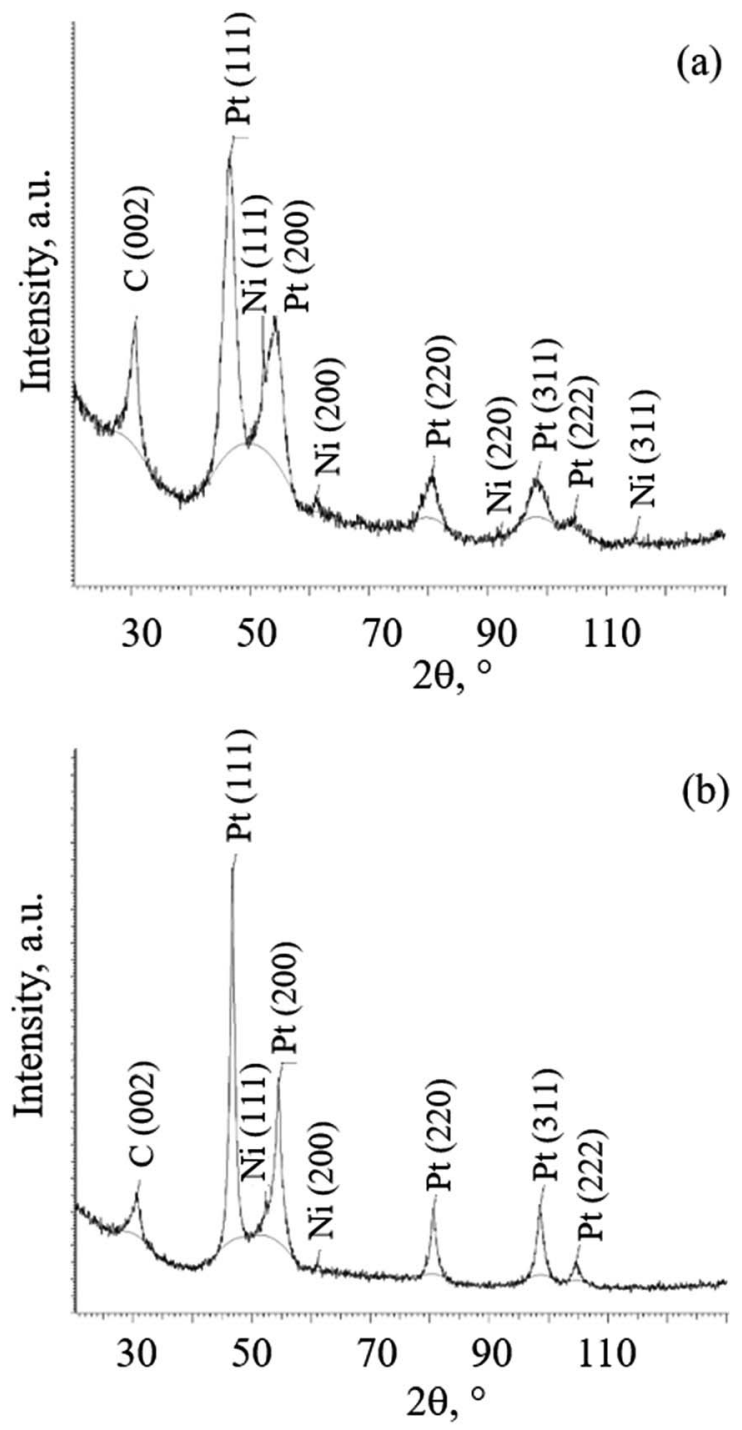

Fig. 11 XRD diffraction patterns of 1 (a) and 3 (b).

Table 2 Pt and Ni crystal lattice parameters $a_{\mathrm{Pt}}$ and $a_{\mathrm{Ni}}$ for different samples

\begin{tabular}{lll}
\hline Sample & $a_{\mathrm{Pt}}, \AA$ & $a_{\mathrm{Ni}}, \AA$ \\
\hline $\mathbf{1}$ & 3.923 & 3.518 \\
$\mathbf{3}$ & 3.916 & 3.526 \\
$\mathbf{6}$ & 3.918 & 3.520 \\
$\mathbf{7}$ & 3.915 & 3.524 \\
$\mathbf{8}$ & 3.913 & 3.521 \\
Pure Pt & 3.924 & - \\
Pure Ni & - & 3.524
\end{tabular}

The calculation indicates that the maximal amount of $\mathrm{Ni}$ in Pt lattice is up to only $2.8 \%$. As Ni nanoparticles in initial CNF play role of seeds for $\mathrm{Pt}$ deposition, we assume that $\mathrm{Pt}$ completely covers Ni nanoparticle and form a needle in the case of needle-like Pt morphology (Fig. S13, see ESI†). In this case, considering quite low value of Ni calculated Ni content in $\mathrm{Pt}$, an alloy forms only at the contact surface between nickel and platinum, and almost is not formed in the rest of $\mathrm{Pt}$ nanoparticle.

\section{Conclusions}

Nanocrystal platinum particle decorated electrospun carbon nanofibers were constructed by the electrospinning of polyacrylonitrile, platinization and modification by thermal treatment at different temperatures under vacuum or hydrogen flow. Platinum crystal nanostructures can be engineered by varying Pt reduction procedure, thermal treatment temperature and medium of thermal treatment. It was found that $300{ }^{\circ} \mathrm{C}$ thermal treatments almost do not change $\mathrm{Pt}$ morphology compared to $100{ }^{\circ} \mathrm{C}$ ones. At the same time, $500{ }^{\circ} \mathrm{C}$ thermal treatment only slightly affects $\mathrm{Pt}$ nanoneedle morphology and leads to Pt ECSA increase for the case when $\mathrm{HCOOH}$ was added immediately on platinization step. The increase of Pt ECSA value is probably related to disappearance of the amorphous structures on CNF which may partially cover the electrocatalyst with saving of nanoneedle Pt crystal structures after treatment. Spherical-like Pt nanoparticles (for $\mathrm{HCOOH}$ addition after $24 \mathrm{~h}$ from the beginning of platinization) degrade by $500{ }^{\circ} \mathrm{C}$ thermal treatment and deactivates $\mathrm{Pt}$ active sites leading to ECSA decrease due to serious sintering of spherical-like Pt nanoparticles. The presented data allows to conclude the possibility of platinum nanocrystal morphology control depending on Pt deposition procedure and further treatment. So that, the thermal treatment at $500{ }^{\circ} \mathrm{C}$ under vacuum of the nanoneedle form of platinum (obtained by immediate $\mathrm{HCOOH}$ addition) is found to be optimal platinum deposition procedure and thermal treatment conditions to obtain the electrocatalyst with highest ECSA. Present investigation of nanocrystalline platinum behavior deposited on carbon nanofibers shows one of the possible ways to design electrocatalysts and to improve performances of gas-diffusion electrodes for polymer electrolyte membrane fuel cells.

\section{Conflicts of interest}

There are no conflicts of interest to declare.

\section{Acknowledgements}

The study was financially supported by Russian Science Foundation (grant \# 18-13-00421). The authors thank Dr K. O. Bazaleeva for the obtaining of XRD results. The electron microscopy investigation was performed using the equipment of the Shared Research Center of Federal Scientific Research Centre "Crystallography and Photonics" RAS. The authors thank the Ministry of Science and Higher Education within the State assignment FSRC "Crystallography and Photonics" RAS in part of XRD results and modelling of electron diffraction patterns. 


\section{Notes and references}

1 Q. Li, D. Aili, H. A. Hjuler and J. O. Jensen, High Temperature Polymer Electrolyte Membrane Fuel Cells, Approaches, Status and Perspectives, Springer, Cham, Heidelberg, New York, Dordrecht, London, 2016.

2 J. Zhang, PEM Fuel Cell Electrocatalysts and Catalyst Layers, Fundamentals and Applications, Springer-Verlag, London, 2008.

3 T. Myles, L. Bonville and R. Maric, Catalysts, 2017, 7, 16.

4 A. Chandan, M. Hattenberger, A. El-kharouf, S. Du, A. Dhir, V. Self, B. G. Pollet, A. Ingram and W. Bujalski, J. Power Sources, 2013, 231, 264.

5 R. K. A. Rasheed, Q. Liao, Z. Caizhi and S. H. Chan, Int. J. Hydrogen Energy, 2017, 42, 3142.

6 A. T. Pingitore, M. Molleo, T. J. Schmidt and B. C. Benicewicz, Polybenzimidazole Fuel Cell Technology: Theory, Performance, and Applications, in Fuel Cells and Hydrogen Production. Encyclopedia of Sustainability Science and Technology Series. ed. T. Lipman and A. Weber, Springer, New York, 2019, pp. 477-515.

7 E. Quartarone, S. Angioni and P. Mustarelli, Materials, 2017, 10, 687.

8 A. Arsalis, Renewable Sustainable Energy Rev., 2019, 105, 391. 9 Y. Liu, W. Lehnert, H. Janssen, R. C. Samsun and D. Stolten, J. Power Sources, 2016, 311, 91.

10 R. Zeis, Beilstein J. Nanotechnol., 2015, 6, 68.

11 S. Authayanum, K. Im-orb and A. Arpornwichnop, Chin. J. Catal., 2015, 36, 473.

12 R. E. Rosli, A. B. Sulong, W. R. W. Daud, M. A. Zulkifley, T. Husaini, M. I. Rosli, E. H. Majlan and M. A. Haque, Int. J. Hydrogen Energy, 2017, 42, 9293.

13 S. S. Araya, F. Zhou, V. Liso, S. L. Sahlin, J. R. Vang, S. Thomas, X. Gao, C. Jeppesen and S. K. Kaer, Int. J. Hydrogen Energy, 2016, 41, 21310.

14 R. Borup, J. Meyers, B. Pivovar, Y. S. Kim, R. Mukundan, N. Garland, D. Myers, M. Wilson, F. Garzon, D. Wood, P. Zelenay, K. More, K. Stroh, T. Zawodzinski, J. Boncella, J. E. McGrath, M. Inaba, K. Miyatake, M. Hori, K. Ota, Z. Ogumi, S. Miyata, A. Nishukata, Z. Siroma, Y. Uchimoto, K. Yasuda, K. Kimijima and N. Iwashita, Chem. Rev., 2007, 107, 3904.

15 S. Chan, J. Jankovic, D. Susac, M. S. Saha, M. Tam, H. Yang and F. Ko, J. Mater. Sci., 2018, 53, 11633.

16 H. Zamora, J. Plaza, P. Canizares, J. Lobato and M. A. Rodrigo, ChemSusChem, 2016, 9, 1187.

17 Y. Jeon, J.-I. Park, J. Ok, A. Dorjgotov, H.-J. Kim, H. Kim, C. Lee, S. Park and Y.-G. Shul, Int. J. Hydrogen Energy, 2016, 41, 6864 .

18 X. X. Wang, Z. H. Tan, M. Zeng and J. N. Wang, Sci. Rep., 2014, 4, 4437.

19 K. S. Han, Y. S. Moon, O. H. Han, K. J. Hwang, I. Kim and H. Kim, Electrochem. Commun., 2007, 9, 317.

20 C. W. B. Bezerra, L. Zhang, H. Liu, K. Lee, A. L. B. Marques, E. P. Marques, H. Wang and J. Zhang, J. Power Sources, 2007, 173, 891.
21 L. Zhang, A. Aboagye, A. Kelkar, C. Lai and H. Fong, J. Mater. Sci., 2014, 49, 463.

22 Z. Dong, S. J. Kennedy and Y. Wu, J. Power Sources, 2011, 196, 4886.

23 M. Inagaki, Y. Yang and F. Kang, Adv. Mater., 2012, 24, 2547. 24 N. Yusof and A. F. Ismail, J. Anal. Appl. Pyrolysis, 2012, 93, 1. 25 V. G. Zhigalina, O. M. Zhigalina, I. I. Ponomarev, K. M. Skupov, D. Y. Razorenov, I. I. Ponomarev, N. A. Kiselev and G. Leitinger, CrystEngComm, 2017, 19, 3792.

26 I. I. Ponomarev, Y. N. Filatov, I. I. Ponomarev, I. Y. Filatov, D. Y. Razorenov, K. M. Skupov, O. M. Zhigalina and V. G. Zhigalina, Fibre Chem., 2017, 49, 183.

27 I. I. Ponomarev, I. V. Blagodatskikh, A. V. Muranov, Y. A. Volkova, D. Y. Razorenov, I. I. Ponomarev and K. M. Skupov, Mendeleev Commun., 2016, 26, 362.

28 I. I. Ponomarev, K. M. Skupov, I. I. Ponomarev, D. Y. Razorenov, Y. A. Volkova, V. G. Basu, O. M. Zhigalina, S. S. Bukalov, Y. M. Volfkovich and V. E. Sosenkin, Russ. J. Electrochem., 2019, 55, 552.

29 I. I. Ponomarev, K. M. Skupov, A. V. Naumkin, V. G. Basu, O. M. Zhigalina, D. Y. Razorenov, I. I. Ponomarev and Y. A. Volkova, RSC Adv., 2019, 9, 257.

30 K. M. Skupov, I. I. Ponomarev, D. Y. Razorenov, V. G. Zhigalina, O. M. Zhigalina, I. I. Ponomarev, Y. A. Volkova, Y. M. Volfkovich and V. E. Sosenkin, Russ. J. Electrochem., 2017, 53, 728.

31 K. M. Skupov, I. I. Ponomarev, D. Y. Razorenov, V. G. Zhigalina, O. M. Zhigalina, I. I. Ponomarev, Y. A. Volkova, Y. M. Volfkovich and V. E. Sosenkin, Macromol. Symp., 2017, 375, 1600188.

32 I. I. Ponomarev, K. M. Skupov, D. Y. Razorenov, V. G. Zhigalina, O. M. Zhigalina, I. I. Ponomarev, Y. A. Volkova, M. S. Kondratenko, S. S. Bukalov and E. S. Davydova, Russ. J. Electrochem., 2016, 52, 735.

33 M. S. Kondratenko, I. I. Ponomarev, M. O. Gallyamov, D. Y. Razorenov, Y. A. Volkova, E. P. Kharitonova and A. R. Khokhlov, Beilstein J. Nanotechnol., 2013, 4, 481.

34 I. I. Ponomarev, I. I. Ponomarev, I. Y. Filatov, Y. N. Filatov, D. Y. Razorenov, Y. A. Volkova, O. M. Zhigalina, V. G. Zhigalina, V. V. Grebenev and N. A. Kiselev, Dokl. Phys. Chem., 2013, 448, 23.

35 I. I. Ponomarev, D. Y. Razorenov, I. I. Ponomarev, Y. A. Volkova and K. M. Skupov, Russ. J. Electrochem., 2014, 50, 694.

36 V. V. Emets, I. I. Ponomarev, V. A. Grinberg, N. A. Mayorova, M. Y. Zharinova, Y. A. Volkova, E. A. Nizhnikovskii, K. M. Skupov, D. Y. Razorenov, V. N. Andreev and I. I. Ponomarev, Russ. J. Electrochem., 2017, 53, 86.

37 I. I. Ponomarev, V. A. Grinberg, V. V. Emets, N. A. Maiorova, M. Y. Zharinova, Y. A. Volkova, D. Y. Razorenov, K. M. Skupov, I. I. Ponomarev and E. A. Nizhnikovskii, Russ. J. Electrochem., 2016, 52, 525.

38 J. Y. Chen, Q. J. Niu, G. K. Chen, J. Nie and G. P. Ma, J. Phys. Chem. C, 2017, 121, 1463.

39 Q. Niu, B. Chen, J. Guo, J. Nie, X. Guo and G. Ma, Nano-Micro Lett., 2019, 11, 8. 
40 H. A. Gasteiger, S. S. Kocha, B. Sompalli and F. T. Wagner, Appl. Catal., B, 2005, 56, 9.

$41 \mathrm{~K}$. Kinoshita and P. Stonehart, Preparation and Characterization of Highly Dispersed Electrocatalytic Materials, in Modern Aspects of Electrochemistry, No. 12, ed. J. O'M. Bockris and B. E. Conway, Springer, Boston, 1977, vol. 183-266, p. 227.

42 W. B. Pearson, A Handbook of Lattice Spacings and Structures of Metals and Alloys, International Series of
Monographs on Metal Physics and Physical Metallurgy, Pergamon Press, London, New York, 1st edn, 1958, vol. 4.

43 G. Bozzolo and J. Ferrante, Scr. Metall. Mater., 1992, 26, 1275. 44 Y. Waseda, K. Hirata and M. Ohtani, High Temp. - High Pressures, 1975, 7, 221.

45 ElementData, Mathematica (8.3.0), Wolfram Research Inc., Champaign, IL, 2018.

46 A. Taylor, J. Inst. Met., 1950, 77, 585. 